\title{
Expanding the Industrial Revolution
}

Meyer, D. R. (2003). The Roots of American Industrialization. Baltimore: Johns Hopkins University Press, Pp. xi, 333, illustrations, maps, tables, notes, bibliography, index, $\$ 45.00$ cloth.

Meyer, D. R. (2006). Networked Machinists: High Technology Industries in Antebellum America. Baltimore: Johns Hopkins University Press, pp. x, 3 I I , illustrations, tables, notes, source essays, index, $\$ 49.95$ hardcover.

Reviewed by: Paul A. Gilje, University of Oklahoma, Norman

DOI: 10.1 177/0096|44209352166

The story of the industrial revolution in America used to be simple enough. In 1789 Samuel Slater - who was trained in the mechanics and management of the textile industry-left Great Britain in disguise and sailed for the United States where he eventually received financial support from Moses Brown and William Almy to build a textile mill in Pawtucket, Rhode Island. Slater depended on the use of entire families to work the machinery in his factory. Over the next few decades factories began dotting the New England countryside, encouraged by the Embargo of 1807 and the War of 1812. After 1815 the Boston Associates, headed by Francis Cabot Lowell, created a textile factory that fully integrated all components of production and developed the use of a unique labor force of young New England women. By the 1830s these efforts in producing textiles had triggered the industrial revolution in the North and set the United States on the path to economic greatness.

This textbook saga, however, obscured as much as it illuminated. To fully understand the history of the industrial revolution, we need to integrate our analysis with the rise of capitalism in North America and place the industrializing process into a larger narrative. Two recent books by David R. Meyer elucidate the larger story of the industrial revolution in America but have some shortcomings and should be examined within the context of other works.

Meyer was trained as a geographer and currently teaches sociology and urban studies at Brown University. At times, his lack of historical background leaps off the page. As a historian, I cringed when Meyer calls the revolutionary generation "visionaries" and implies that John Adams and Thomas Jefferson attended the Constitutional Convention (see Roots, p. 16). I was also somewhat distressed by the lack of research in primary material, and I struggled with his writing style - with phrases such as "developmental impacts" and "resource endowments" - that turgidly underwhelmed the reader with example after example and statistic after statistic. But putting these criticisms aside, Meyer's work deserves a careful reading by historians and contributes to our understanding of the expanding industrial revolution.

Meyer directly connects industrialization with the rise of capitalism. In The Roots of American Industrialization, Meyer argues that the success of eastern agriculture triggered the industrial revolution from 1790 to 1860 . Building on the work of scholars with as diverse arguments as Christopher Clark and Winifred Barr Rothenberg, Meyer notes that when farmers increased productivity, reduced costs, and enhanced efficiency, the demand for consumer goods grew, excess capital for investment became available, and labor was freed to work in manufacturing. ${ }^{1}$ 
This concern with the relationship between the rise of capitalism and industrialization, however, remains focused on the countryside, where Meyer believes much of the capital for industrialization originated. He thus sidesteps the role of commerce and the creation of excess capital belonging to merchants. This approach is surprising since he centers so much of industrialization on port cites. Using his skills as a geographer, Meyer demonstrates how industrialization began in several "cores" centered on different cities-New York, Philadelphia, Boston, and Baltimore. He also shows that each core had a set of satellite cities that contributed to industrialization. New York's manufacturing was the most diverse, Philadelphia less so. Boston and its environs had a greater concentration on textiles and shoemaking. Baltimore had the most limited satellite region.

He also does not believe that several other key elements of the rise capitalism-banking corporations and transportation changes - influenced industrialization. Meyer briefly considers the rise in banking but argues that these engines of capital creation did not directly fund many new industrial enterprises. Likewise, he never examines the development of the corporate form of enterprise. Corporations may not have funded many manufacturing enterprises in the opening decades of the nineteenth century, but they became an increasingly important means of raising capital for industry closer to the Civil War. Meyer challenges traditional assumptions about the role of the transportation revolution in industrialization. By emphasizing the East Coast hubs and their satellite regions, and by centering the spread of markets to these urban areas and their surrounding countryside, Meyer discounts the role of the expansion of settlement to the Midwest and the importance of slavery in the South to industrialization in the North (slavery does not even appear in the index of either book). Meyer claims that the Midwest and the South together took between 10 and 15 percent of the East's manufactured goods. Meyer thus believes that the canal boom had little real impact on industrialization, except in facilitating the development of a satellite industrial region near the Erie Canal and the local shipment of coal in Pennsylvania. Likewise, "railroads contributed minimal direct economic benefits until the late 1850s" (Roots, p. 156). Instead, since most goods were moved only short distances and needed flexible routes, wagons remained the central means of transportation. Consumerism, which Meyer recognizes as important for industrialization, took hold largely in the cities and their surrounding hinterland. This analysis, however, ignores coastal shipping, which remained a crucial means of sending goods to the South until the outbreak of the Civil War. It also discounts the markets the South provided for textiles, shoes, and processed food. A comprehensive study of the industrial revolution needs to take a national and not just a regional approach.

Examining industrialization on the national scene does not preclude concern with regional and local developments. The Roots of American Industrialization is a provocative book that reconsiders the industrial revolution in new ways. Meyer also introduces some important ideas that he develops further in Networked Machinists. In The Roots of American Industrialization, Meyer argues that industrial success depended on good management, access to mechanical skills, and investment capital conservatively applied to the development of factories and machinery. These insights, especially as related to good management and mechanical skills, form the core of Networked Machinists. Meyer believes that the key to industrial development in the high technology industries of iron, textiles, and firearms in the antebellum period was the emergence of networks of machinists. These machinists exchanged information on technical developments through personal and family connections as they shifted from factory to factory within the Northeast and between particular hubs of industrial activity. The earliest networks developed in iron foundries, but textiles and firearms were also important. Often machinists were recruited from well-to-do families, but many were also brought up through the ranks based on skill and intelligence. As these individuals moved on to supervise factories, they joined the nation's social and economic elite. This highly mobile group — both geographically and socially—spread the 
technology that became the hallmark of industrialized America. Meyer thus demonstrates the interconnectedness of the various sectors involved in industrialization.

Networked Machinists makes a greater contribution to our understanding of the industrial revolution than The Roots of American Industrialization since it has a stronger research base and offers sounder proof of its assertions. Networked Machinists also explains how industrialization spread geographically and entailed developments in several areas of production. Similar to The Roots of American Industrialization, in Networked Machinists Meyer uses his expertise in geography to underwrite key elements of the argument. In particular, Meyer provides a series of charts, maps, and graphs demonstrating the interconnectedness among different manufacturing core areas. For example, Meyer argues that machinists trained by Samuel Slater moved out from the "Providence Area Hearth" to establish mills in the Quinebaug Valley in Connecticut, in the New Ipswich area of New Hampshire, in the Upper Hudson Valley and the Utica area in New York, and even in Philadelphia (see Networked, p. 53, map 2.1). To substantiate these claims, Meyer includes a prosopography of hundreds, if not thousands, of machinists, detailing where they were trained, to whom they were related, and the different factories where they worked.

Meyer provides an important perspective on industrialization by looking at textiles as only one - and not even the most important - of several high technology industries where innovation in machinery was crucial to industrial development. Meyer begins with iron foundries and sees them as early hubs of machinist networks. However, it was not simply the iron foundries that were essential to technological development but the interest of some members of the elite and engineers in the development of the use of steam engines made out of iron that led to innovation in machinery. A similar alliance between the elite and those with mechanical skills bred a community of cotton textile machinists, perhaps best exemplified by the alliance among Slater, Almy, and Brown. Meyer also discusses firearms as a third area of high technology networking. All three areas by the 1840 s and 1850 s overlapped to some degree with networks of machine tool experts not only traveling between hubs in the Northeast but also jumping between industries.

Meyer also contributes to our understanding of the expanding industrial revolution by arguing that an increase in manufacturing does not necessarily include the creation of large power-driven factories. Several scholars have already suggested this point. Over twenty-five years ago studies of the shoe industry demonstrated that at least in this area of production it was possible to dramatically increase output by simply reorganizing the work force in the Boston region and in Philadelphia. ${ }^{2}$ More recently, Jonathan Prude argues that "industrialization is best understood as a form of manufacturing generating expanded volumes of cheap goods intended for sale through extensive market networks." From this perspective, industrialization could include "building upon, and supplanting, craft manufacturing" and might or might not entail major changes in technology. ${ }^{3}$ Following Prude and Meyer, then, would mean a redefinition of industrialization that would include nonfactory production unaided by machines.

Meyer, however, does not fully explore the implications of this redefinition of industrialization in two crucial areas of production in this period. First, he largely ignores expansion of household manufacturing. As Laurel Thatcher Ulrich and others demonstrate, merchants sought women willing to devote time, or the time of young women attached to their household, to the production of yarn and cloth. The number of spinning wheels in the New England countryside greatly increased in this period and produced twice as many textiles in 1790 as they had in 1770 . The role of women in manufacturing, which remained important in the industrial economy throughout the nineteenth century, is thus underplayed in Meyer's analysis. ${ }^{4}$

Second, despite having an expansive definition of industrialization, Meyer spends little time examining the spread of artisanal production. If women remained the main weavers in New England during the early republic, starting in the 1790s in the Philadelphia region, the arrival of male immigrant artisans provided most of the labor in weaving and producing cloth. In other 
words, in both New England and Pennsylvania a great deal of the early textiles were woven by individuals rather than machines, regardless of how the thread was produced..$^{5}$ As the example of the Philadelphia weavers demonstrates, artisanal production grew beginning in the 1790s. Central to this development was the growth of both overseas and domestic trade. Some of this manufacturing occurred in shops and resulted from the training of more skilled journeymen in a host of crafts. But some of it also reflected changes in the traditional workshop, including the partial training of workmen who would specialize in making components of an item rather than learning the "art" and skill of crafting the entire finished product. Some masters, such as those in the shoemaking industry, increased production by using a system of outwork, where journeymen took the raw material from the master to their own homes and workshops. These developments led to greater economic distances between master and journeymen, creating conflict that led to strikes in the 1790s and early 1800s. Simultaneous with the emergence of class conflict there developed an entrepreneurial class. The masters who became businessmen developed cash reserves that might be invested in other activities. It would also be interesting to know how many masters invested in the machinery and factories that attract so much of Meyer's attention.

Although Meyer has some valuable insights into industrialization, ultimately the industrial revolution was a longer, larger, and more complicated process than appears in either Networked Machinists or The Roots of American Industrialization. Meyer ignores some important industrial antecedents. Shipbuilding was crucial to the colonial economy. As many as one-third of all British vessels in 1775 were constructed in North America. Shipyards employed hundreds and distributed their product in an international market. Although shipyards lacked key elements that would later be associated with the industrial revolution-work was organized around skilled crafts and there was limited use of power-driven machinery to enhance output - their size, complexity, and capital outlay made them important precursors to later industrialization. Moreover, the most skilled shipwrights were technologically innovative, at times moved from shipyard to shipyard, became managers, and "networked" in a manner similar to the machinists studied by Meyer.

Other enterprises that had the look and feel of factories in the eighteenth century might suggest a continuum with later developments. In particular, lumber mills used power-driven machinery but often were of a small scale without many employees. Sugar refineries located in the port cities had complex machinery, although they usually relied on man power. Careful study of the technology, capital arrangements, and developments in machinery in these other areas of production might reveal a longer history of networking than appears in Meyer's analysis.

Perhaps more relevant for Meyer were the early developments in the iron industry. Iron furnaces in the countryside ranging from Virginia through New Jersey produced a significant amount of iron in the eighteenth century. The geography of the industry is important since it included some areas not covered by Meyer. So too was the labor force, which employed slaves as well as white workers. Some of those slaves were skilled laborers akin to the earliest machinists who probably never became a part of Meyer's networks. Moreover, given that the Potomac region was the seat of James Rumsey's steamboat experimentation, the area included innovators in the steam technology Meyer considers central to his story. John Bezís-Selfa has written an excellent study of the early iron industry, showing the importance of skilled laborers and managers to the production of iron, which might have served as a precursor to the development of networked machinists discussed by Meyer. Knowledgeable foundry workers often moved, exchanged technology, and became managers. ${ }^{6}$

Politics, too, is an essential part of the story. Although Meyer packs his work with economic detail, he avoids discussing political developments. Not including the longer story in tracing the roots of industrialization, and the absence of an analysis of government policy, fails to provide a full explanation of the timing of the industrial revolution. The Revolutionary War, for 
example, brought some opportunities to expand manufacturing, but the disruptions that came with the conflict limited the war's impact on industrialization. Only after the war did more serious discussions of industrialization lead to new efforts at manufacturing. Even during the 1780s, often heralded as a period of economic crisis, the first stirrings of the industrial revolution appeared. The U.S. Constitution implicitly sought to support manufacturing by granting Congress the power "to promote the Progress of Science and useful Arts, by securing for limited Times to Authors and Inventors the exclusive Right to their respective Writings and Discoveries." As Doron Ben-Atar shows, the Patent Act of 1790 (revised in 1793 and 1800) may have provided some meat behind these intentions but also led to trade piracy by tacitly allowing individuals to claim foreign inventions as their own as long as no one else had patented the machine or invention within the United States. ${ }^{7}$

Similarly, the political and ideological roots of industrialization were essential in encouraging economic change. Lawrence Peskin shows how the Federalist abandonment of industrialization in favor of overseas trade after the electoral victory of Thomas Jefferson, and the Republican movement in the opposite direction, set the stage for an expansion of the industrial revolution. Had the Republicans remained entirely wedded to their original agrarian ideology, far more political opposition to the development of industry would have existed. Peskin also traces the emergence of large-scale manufacturers who pursued a new mercantilism that pushed for government involvement in the American economy and the rise of the industrial revolution. This proindustrial lobby led to the organization of associations and articulated its ideas in newspapers and other publications. ${ }^{8}$

The importance of politics to industrialization can be seen in the debates over tariffs. At the conclusion of the Revolutionary War, import duties emerged as an issue related to the encouragement of manufacturing. Merchants and business leaders in the cities in the 1780s and 1790s argued for the development of more industrial production and organized a host of supportive manufacturing societies. Along with the upwardly mobile mechanics-master craftsmen who sought more production - the merchants and business leaders lobbied for protective tariffs. In the 1780s states such as Massachusetts, Pennsylvania, and New York passed some protective tariffs. Although the main reason for the federal impost of 1789 was to gain revenue, it included extra duties to protect some industries. In 1792 a new tariff expanded the list of protected products. As secretary of the treasury, Alexander Hamilton authored his famous Report on Manufactures (1791) in which he urged the national government to offer bounties and other incentives to encourage manufacturing. Demonstrating the about-face described by Peskin, Jeffersonian Secretary of Treasury Albert Gallatin wrote a report in 1810 "for the purpose of protecting and fostering the manufactures of the United States." Although less philosophical in tone than Hamilton, Gallatin provided a comprehensive survey of the vast array of manufacturing already taking place in the country and sought ways to increase production. The federal government produced a similar survey of U.S. industry in 1814. After 1815, although tariff policy gyrated back and forth, protective tariffs encouraged the process of industrialization.

Meyer's books thus add to our understanding of the industrial revolution but remain narrowly focused. The Roots of American Industrialization is less a complete discussion of the origins of industrialization and more a partial and somewhat flawed examination of how and why the Northeast industrialized. Networked Machinists is a better book with less lofty goals. It explores one aspect of the industrialized process centered on the engineers and managers who were the driving force in the technological change in iron manufacturing, textile production, the making of firearms, and crafting machine tools. Meyer's books aid us in seeing the importance of the rise of capitalism in this process and begin to extend the boundaries of industrialization but do not provide a full picture of the expanding industrial revolution. 


\section{Declaration of Conflicting Interests}

The author declared no conflicts of interest with respect to the authorship and/or publication of this article.

\section{Funding}

The author received no financial support for the research and/or authorship of this article.

\section{Notes}

1. Christopher Clark, The Roots of Rural Capitalism: Western Massachusetts, 1780-1860 (Ithaca, NY, 1990); Winifred Barr Rothenberg, From Market-Places to a Market Economy: The Transformation of Rural Massachusetts, 1750-1850 (Chicago, 1992).

2. Alan Dawley, Class and Community: The Industrial Revolution in Lynn (Cambridge, MA, 1976); Bruce Laurie, The Working People of Philadelphia, 1800-1860 (Philadelphia, 1980).

3. Jonathan Prude, "Capitalism, Industrialization, and the Factory in Post-Revolutionary America," in Paul A. Gilje, ed. Wages of Independence: Capitalism in the Early Republic (Madison, WI, 1997), 86.

4. Laurel Thatcher Ulrich, The Age of Homespun: Objects and Stories in the Creation of an American Myth (New York, 2001).

5. Adrienne D. Hood, The Weaver's Craft: Cloth, Commerce, and Industry in Early Pennsylvania (Philadelphia, 2003).

6. John Bezís-Selfa, Forging America: Ironworkers, Adventurers, and the Industrious Revolution (Ithaca, NY, 2004).

7. Doron S. Ben-Atar, Trade Secrets: Intellectual Piracy and the Origins of American Industrial Power (New Haven, CT, 2004).

8. Lawrence A. Peskin, Manufacturing Revolution: The Intellectual Origins of Early American Industry (Baltimore, 2003).

\section{Bio}

Paul A. Gilje is George Lynn Cross Research Professor in the Department of History, University of Oklahoma in Norman, OK. 